\title{
PERFORMANCE INFORMATION DISCLOSURE AT THE ESTONIAN UNIVERSITIES
}

\author{
Toomas Haldma \\ University of Tartu, Estonia \\ Kristi Ploom \\ University of Tartu, Estonia \\ Anneli Lorenz \\ University of Tartu, Estonia
}

\begin{abstract}
The main purpose of this paper is to examine the performance information disclosure, its objectives and used performance measures at Estonian public universities. The present study focuses, using the PDCA (Plan-Do-Check-Act) cycle model on the linkages between disclosed performance information in various stages of performance management cycle. This study uses predominantly document analysis, describing and analysing the performance information in strategic plans, budget strategies and annual reports on a six public Estonian universities. Additionally, a number of interviews have been conducted to explore some qualitative aspects of performance measurement issues at Estonian universities. Paper also focuses on financial and non-financial indicators presenting performance of three main areas of university operations - teaching, research and service to the society activities. The findings reveal that the financial and non-financial performance indicators are weakly linked within the performance measurement of the main areas of university operations. Considering the influential factors affecting the improvements of performance measurement, legal regulatory requirements continue to have a substantial impact in Estonian universities.
\end{abstract}

Keywords: performance information, financial and non-financial indicators, universities, Estonia

JEL codes: H83, I23, M41

\section{Introduction}

The last decade has significantly increased discussion on the autonomy of universities, performance, accountability, financial sustainability and their relationships within the European research community. Particular emphasis is addressed on performance measurement and performance management. University role is generally concentrated around three clusters of activities - teaching, research and service to the society and a university is expected to perform in each of these areas. Literature revealed that there has been an important move to investigate performance measurement issues at the universities in Western countries (see Warning, 2004; ter Bogt and Scapens, 2012; Kallio and Kallio, 2014), but we have not find any studies on the topic in Central and Eastern European countries. Attempting to fill the literature gap on country-specific studies in the new EU member states, this paper aims to assess the extent of development and implementation of performance management systems in Estonian public universities and analyze the disclosure of performance information by the universities.

The present study focuses, using the PDCA (Plan, Do, Check, and Act) cycle model (Deming, 2000) framework, on the linkages between performance information within different stages of performance management cycle in continuous feedback loop. Such an approach is appropriate as different stages play different roles in the performance management process in practice. 
Recognizing the need for the development of performance management of the universities, this paper aims to explore the financial and non-financial performance information disclosed by the universities in three main areas of their operations - teaching, research and service to the society activities.

The research issues addressed in this paper are as follows:

1. Which performance information use Estonian public universities use within different stages of performance management cycle within the main areas of their operations teaching, research and service to the society activities?

2. What are the main performance measures disclosed by the universities?

This study was conducted basing on the data of 2012-2015. This period was extremely challenging for Estonian universities, as the operating circumstances have been improved substantially in the following directions.

First, new development plans of the universities. In four Estonian public universities the development plans period was ending in 2015 and for two universities the new development period began in 2015. As the number of students is decreasing, the compilation of a new development plan requires a better definition of strategic objectives, better design and execution of budgets as well as an efficient use of resources and activities in order to ensure the effectiveness.

Second, the university funding policy change. From 2013 financing of university teaching activities is based on a governance agreement between the Ministry of Education and Research and an university for three years. This agreement is split into annual performance agreements. First governance agreement period was from 2013 to 2015. The performance agreement puts an obligation to the university to objectively evaluate educational activities to ensure their sustainability and effectiveness of activities. The latter is influenced by performance measurement systems of the universities. In research area there are going on the changes in target financing systems and also in institutional research grants (IUT) and personal research grants (PUT) financing systems.

Third, an institutional accreditation. In 2012-2015 there were taking place the institutional accreditations in all universities to assess the university management, organization, teaching and research activities in compliance with legislation, the objectives and the development plan of the university. Accreditation allows the university to monitor and redesign its internal organization and operating guidelines, and also the key performance indicators of teaching, $\mathrm{R}$ $\& \mathrm{D}$, and creative activities.

Fourth, changes in university governance. Several universities in recent years are occurring changes in organizational structure. For example, the merger of the structural units of the University of Tallinn is resulting in five interdisciplinary research- based focus-area. Since 2016 the faculties and institutes are grouped within four areas (realia, humaniora, medicina ja socialia) at the University of Tartu. The highest governance institutions at the University of Tartu and at the Tallinn University of Technology include the members outside of the university to have better linkage with the society.

The study uses primarily document content analysis, describing and analyzing the performance information from the public accountability perspective. The information contained in strategic and operational plans, budgets and annual reports of six public universities of Estonia in 2010-2013 is reviewed, analyzed and discussed. The research was supported by Research and Innovation Policy Monitoring Program financed by the European Social Foundation. 
The rest of the paper is structured as follows. First an overview of the theoretical framework concerning public accountability and performance measurement framework is given. The second part gives a short overview of the methodology used. The third part is describing the regulatory framework of accountability and performance measurement in Estonian public universities. The fourth part is based on the results of the analysis of disclosed financial performance information in the annual reports of six Estonian public universities which will be followed by non-financial performance measurement approaches on teaching and research activities and service to society. To conclude the paper, a number of concluding remarks are highlighted.

\section{Theoretical framework of the study}

According to Grossi et al. (2016), performance information is expected to be important in various phases and for developing different concepts and tools of public management. Ter Bogt'i and Scapens (2012, p. 451) point out, that the measurement of research and teaching performance is increasingly common within the universities, driven probably by the rise new public management (NPM). NPM focuses on improving performance e.g. efficiency and effectiveness in public sector. Bovens (2005), and Brandsma and Schillemans (2013) stress that accountability presented as an essential path to efficiency and effectiveness. According to Bovens (2005), public accountability first relates to openness, provided by information disclosure at least accessible to the main stakeholders. But Messner (2009) acknowledges that there are certain limits to accountability and Greiling and Spraul (2010) specify the reluctance to disclose information and deliberate information overload as the main issues concerning accountability. According to Hood (1995) NPM emphasizes accountability and efficiency through the use of explicit quantitative performance measures. However, Lapsley (2008) emphasises performance measurement as a key feature of NPM as it reflects the desired objectives as well as the actual outcomes of an organization.

Considering the further focus on integrated performance management at the universities, linking financial and non-financial performance information into the continuous feedback loop financial management cycle, we use the PDCA cycle to assess the quality of performance information, disclosed by universities. The PDCA (Plan-Do-Check-Act) cycle (Deming 2000) was originally used in organizations as management cycle for continuous improvement and learning. Epstein and Campbell (2002) describe a performance management model basing on a PDCA-cycle which consists of four stages:

- strategic and annual planning (Plan);

- performance budgeting (Do);

- performance measurement and reporting (Check);

- performance-based decision making (Act).

According to Schedler and Siegel (2005), in ideal situation the strategies and budgets are linked with each other, in order to enable strategy implementation in practice. Therefore, we can conclude that budgets and accounting (performance) reports form very important elements of the universities performance management cycle in continuous feedback loop and all the stages of the PDCA cycle can be seen as different elements of performance management.

Also Guthrie ja Neumann (2007, p. 240) point out that university management operations are conditioned by resourcing, budgeting, performance measurement and reporting, which are inter-related. These relations can be followed within the PDCA cycle framework. Universities need to plan operations strongly upon the availability of resources and budgets, which are 
subject to government policies (ibid). From other side, universities are expected to account for use of resources and overall performance.

Vernau (2014, p. 563) believes that competition will increase the role of strategic management in universities. The development of strategic management should be supported by strategic management control. But Vernau (ibid) also notes that strategic management control is still at an early stage of development at the universities.

According to Van der Stede (2011, p. 606), an increased demand for disclosures is one of the main implications of the economic crises. He added that "never before there has been as strong a feeling that organizations did not perform as they should have" (ibid). Therefore, as a consequence of the crises, Van der Stede pointed out that there was expanded an idea to improve more direct regulations of practices to enhance disclosures that presumably act as a disciplining mechanism by way of increased transparency (ibid). Also the requirements of the governance agreements and performance agreements of Estonian universities to disclose in management reports of the annual reports the most important performance indicators of the governance agreements, can be seen as an attempt to increase the volume of information disclosure in annual reports. Guthrie and Neumann (2007, p. 240) and Coy and Dixon (2004) revealed that performance information in university annual reports has been as a research object since 1990s already.

Still ter Bogt ja Scapens (2012, p. 452) claim that there has been very litte research into the nature and consequences of performance measurement within universities. However, we can find a number of studies on performance measurement and management issues of the universities in Sweden (Modell, 2003), Finland (Kallio and Kallio, 2014), Australia (Worthington, Lee, 2008; Guthrie and Neumann, 2007), USA (Coy. et al, 2001), Germany (Warning, 2004), China (Kuah and Wong, 2011) and in other countries. In some countries, for example, in Germany (Greiling, 2010), Hong-Kong (Chen et al., 2006), Fiji (Lawrence and Sharma, 2002) a.o., there has been implemented Balanced Scorecard to improve performance measurement and management systems at the universities. But there seems to be not any study on the topic in Central and Eastern European countries.

According to Guthrie ja Neumann (2007, p. 244) the development and use of performance indicators (measures) is connected with several political and technical aspects:

- who develops indicators;

- how they are reported;

- who assesses the information;

- the purpose for which the information is used etc.

The performance indicators are needed for both, for internal (university) as well as for external users. Melkers and Willoughby (2005) argue that the indicators provide university performance characteristics outward (by a competent evaluator or assessor) and within the university (e.g., through a self-assessment).

Kaplan and Norton (1992) and Horvath et al. (2006) argue that the performance measures have to involve as financial as well as non-financial measures. Also Coy et al. (2001, p. 24) and Vernau (2014, p. 562) point out that both groups of indicators have an important role within the performance measurement systems of the universities.

At Australian universities there has been intensively investigated and implemented the performance indicators which are mainly distinguished into four groups (Guthrie and Neumann, 2007, p. 240): 
- institutional context;

- teaching and learning;

- research and professional service; and

- participation and social equity.

As the above-mentioned authors point out, the Australian universities are required to report annually not only outputs and outcomes, but also embracing indicators for 'value added' and educational 'impact'.

The study conducted in United States (see Coy et al., 2001, p.16) showed that university stakeholder expectations on information disclosure will focus on five main areas : educational activities, research, various general performance indicators (efficiency and effectiveness, especially of learning activities in conjunction with the number of graduates etc.), resource allocation and overhead distribution. The latter areas relate to the cost aspects of financial performance.

\section{Research method}

The current empirical study can be divided into two stages. The first stage involved the structures of strategic documents and annual reports, and analysis of dynamics of performance measurement and management of financial and non-financial aspects (e.g. indicators) reflected in these documents and reports of the Estonian six public universities Tallinn University of Technology, Tallinn University, Estonian University of Life Sciences, Estonian Academy of Music and Theatre, Estonian Academy of Arts and University of Tartu.

The second stage of the study carried out a qualitative analysis of methodological elements of performance measurement and management practice of Estonian universities. This qualitative analysis can be further divided into two sub-phases. Within the first sub-phase financial and non-financial performance indicators of the each main activity areas (teaching, research, service to society) were analyzed. Thus, the current study is basing on multiple-case approach (multi-case study).

The second sub-phase of the qualitative study involves the analysis of structured interviews conducted with the leading persons of the main areas (teaching, research etc.) of the university.

Altogether, within the current study there have been conducted the following analyses:

1) Analysis of performance indicators presented in annual reports of six public universities during 2008-2013;

2) Analysis of performance indicators presented in strategic documents (development plans, budgeting strategy, R\&D strategy a.o.) in 2008-2013;

3) Analysis of performance indicators presented in the annual reports of non-profit organization Universities of Estonia in 2005/2006-2012/2013.;

4) Analysis of legal regulations (Act on Accounting, governance and performance agreements between the universities and Ministry of Education and Research) on performance measurement of the Estonian universities;

5) Analysis of the interviews conducted with altogether 24 experts from six Estonian universities. The interviews were based on a structured questionnaire (34 questions).

\section{Regulatory framework on performance information disclosure at the universities}

Estonian universities operate as autonomous public legal persons. As it was pointed out by Pallot (2001, p. 653), central legislation may play an important role in driving change in 
public sector. This aspect should be taken into account when designing, assessing and developing the principles and methods of performance measurement at the universities. Our analysis revealed that performance information disclosure at the universities have influenced by following regulations:

- Estonian Act on Accounting;

- Governance and performance agreements conducted between the universities and Ministry of Education and Research.

According to the Estonian Act on Accounting (§ 24), a management report of an annual report shall provide an overview of the activities of the accounting entity, circumstances which are material to the assessment of the financial position and business activities of the accounting entity, significant events which have occurred during the financial year and the likely future developments in the following financial year. Consequently, the management report should disclosure the dynamics of the operations and performance of the universities.

The Act also specifies that the management report of the organizations whose annual reports are audited or must be audited (e.g. universities) shall set out, inter alia:

1) the main areas of activity, product and service groups;

2) general (macroeconomic) development of the activities environment of the accounting entity and the impact of such development on its economic performance;

3) whether the operating activities of the accounting entity take place on a seasonal basis, or whether their business activities are cyclical;

4) the most significant investments made during the financial year and planned in the next future;

5) significant projects in the field of research and development and the related expenditure in the accounting year and the following years;

6) the main financial ratios concerning the financial year and the preceding financial year, and the methods for calculating the ratios.

Consequently, proceeding from the Act on Accounting and the main areas of the activities, the management reports of Estonian universities should include a meaningful analysis of the current state of the organization (university), its operating environment, and development plans. It also highlights the different legal aspects of linking an organization's financial performance and risk hedging. Thus, it is expected that the management report describes various activities associated with overall financial perspective and position of a university.

Governance and performance agreement between the Ministry of Education and Research and a university will specify the funding for teaching activities for three years. This agreement is split into annual performance agreements. First governance agreement period was from 2013 to 2015. The performance agreement puts an obligation to the university to objectively evaluate educational activities in the different curricula to ensure their sustainability and effectiveness of activities, which are influenced by performance measurement systems of the universities.

\section{Financial performance measurement at the universities}

Several authors (see Coy et al., 2001; Vernau, 2014) have pointed out that the financial indicators of performance measurement have an important role in university performance management systems. The role of financial ratios among performance measurement issues of the universities has been estimated by Coy and Dixon (2004, p. 90) as more important ones compared to other performance characteristics. But Vernau (2014, p. 557) argues that the 
universities are more focused on non-financial indicators of teaching and research activities comparing with financial indicators. This section will analyze financial performance indicators presented in the management reports of the Estonian universities. Table 1 shows an overview of the main groups of disclosed financial indicators in management reports of Estonian universities in 2014.

Table 1. Financial performance indicators in management reports of Estonian universities

\begin{tabular}{|l|c|c|}
\hline Group of indicators & $\begin{array}{c}\text { Number of absolute } \\
\text { value indicators }\end{array}$ & $\begin{array}{c}\text { Number of } \\
\text { ratios }\end{array}$ \\
\hline General indicators & 12 & 2 \\
\hline Financial ratios & - & 11 \\
\hline Revenue general indicators & 3 & 6 \\
\hline Revenue indicators of teaching activities & 6 & 8 \\
\hline R\&D revenue indicators & 19 & 12 \\
\hline Expenses indicators & 6 & 5 \\
\hline Total & 46 & 42 \\
\hline
\end{tabular}

Source: authors' analysis.

Table 1 indicates that the absolute value indicators are used more intensively than ratio indicators. There are more $R \& D$ revenue indicators in use at the universities - altogether 31 different indicators. Significant group of measures form 14 revenue indicators of teaching activities. Also 11 different financial ratios are used. Table 2 gives an overview on financial ratios presented within the management reports of Estonian universities.

Table 2. Financial ratios presented in management reports of Estonain universities

\begin{tabular}{|l|c|c|}
\hline Group of indicators & $\begin{array}{c}\text { Number of ratios in the management } \\
\text { reports of the universities }\end{array}$ & $\begin{array}{c}\text { Number of ratios in the annual } \\
\text { reports of Universities Estonia }\end{array}$ \\
\hline Liquidity ratios & 2 & 1 \\
\hline Leverage ratios & 4 & 3 \\
\hline Activity ratios & 1 & 1 \\
\hline Profitability ratios & 2 & - \\
\hline General ratios & 2 & 2 \\
\hline Total & 11 & 7 \\
\hline
\end{tabular}

Source: authors' analysis.

Analysis of financial ratios (see Table 2) revealed that most of the universities as well as NPO Universities Estonia recognize leverage ratios (long-term solvency ratios). These indicators are debt ratio (debt to total assets), equity ratio (the ratio of equity and total assets), the ratio of loans and operating income, loans and total assets ratio a.o. The latter three ratios are represented also in the annual report of Universities Estonia (Council of Rectors of the universities). Among liquidity ratios, universities present current ratio (current assets to shortterm liabilities) and quick ratio (current assets - inventories - prepayments / current liabilities). The current ratio is also used as an indicator of Universities Estonia (Rectors Council) annual report. Among activity ratios Operational efficiency indicator as a ratio of operating expenses and operating revenues are used. Profitability indicators are not used by public universities, but presented by one private Estonian university. Our analysis revealed, that between 2011-2013, there are certain improvements in use (disclosure) of financial ratios in management reports. In the 2014 management reports most of ratios disclosed by three universities - the Tallinn University, Estonian Academy of Music and Theatre, and University of Tartu - present seven different financial ratios in their management reports. The list of the ratios of those universities coincides with the list of ratios disclosed in Universities Estonia (Rectors Council) annual report. Two universities have not disclosure any financial ratios in 
their management reports. Our analysis revealed that the presentation of financial ratios is expanded during the last decade at Estonian universities and the list of ratios presented in the Universities Estonia annual report form of a well-established base of indicators, which could extend to all Estonian universities and higher education institutions.

However, a number of financial officers of the universities recognized within the interviews that, the requirement of the Act of Accounting to present the most important financial ratios within the management report, has positively impacted both, the presentation of the financial ratios as well as regular analysis and monitoring of financial statements of the universities.

To assess the extent of implementation of performance management systems in Estonian public universities, we analyzed how the measures disclosure by the universities in annual reports are reflected in planning strategic documents - in development plans and budgeting strategy. Our analysis revealed that financial measures are in very limited manner presented in development plans and budgeting strategy. Only one university has formed certain target through a debt ratio in its budgeting strategy. Therefore, we can conclude that the strategic planning is weakly linked to other stages of the Deming's cycle in the area of financial targets and measures.

\section{Non-financial performance measurement}

\subsection{Teaching activity performance measurement}

Non-financial performance indicators of teaching activities can be distinguished in three groups: 1) academic performance and students' indicators; 2) curriculum development indicators, and 3) study supporting processes indicators. Our analysis revealed that the Estonian universities used 32 different indicators of teaching activities. At the same time, the choice of indicators is very different from university to university. There are only two indicators which are reflected in management reports of all universities in 2014 - the number/share of foreign students and academic staff number/share. Within the study supporting processes indicator group, internationalization indicators are most intensively used. General overview on the non-financial performance indicators of teaching activities of Estonian universities in 2014 is given in Table 3.

Typically, universities do not disclose alumni' employment-related indicators. Probably the reason for that is the non-availability of corresponding data and that such data is not feasible to collect on annual basis. However, in 2013, one Estonian university has significantly improved its management report and presented, among other indicators, also the alumni employment figures.

Our document analysis and interviews revealed that there is missing an appropriate list of cost objects at the universities. Therefore, it is complicated to specify which costs should be considered in the guidelines as direct cost or indirect costs. As a consequence, the interviews showed that the definition of direct and indirect costs vary substantially at the universities. In similar, interviews revealed that a detailed accounting object (e.g. study program) is not covered by costing methods e.g. the costs of different study programs are not usually calculated. Estimated calculations are arranged mainly for the opening of the study program (curricula), further cost budgeting and monitoring are not developed. This refers to an incomplete PDCA cycle and to a non-evaluation of the costs of curriculum. However, the total resources spent on the curricula form a significant share of teaching activities of the universities. 
Table 3. Teaching performance indicators presented in management reports of the universities

\begin{tabular}{|c|c|c|c|}
\hline Area & Group of indicators & Indicators & $\begin{array}{c}\text { Number of } \\
\text { universities using } \\
\text { the indicator }\end{array}$ \\
\hline \multirow{14}{*}{$\begin{array}{l}\text { Teaching } \\
\text { performance } \\
\text { and students }\end{array}$} & \multirow{5}{*}{ Number of students } & Number of students & 4 \\
\hline & & Number/share of master/doctoral students & 4 \\
\hline & & Number/share of part-time students & 4 \\
\hline & & „Market-share“ of the university* & 1 \\
\hline & & Annual student admissions & 4 \\
\hline & \multirow[t]{3}{*}{ Academic progress } & Number/share of discontinued students $* *$ & 5 \\
\hline & & Ratio of student admission/graduation & 1 \\
\hline & & Share of full-time students & 1 \\
\hline & \multirow[t]{6}{*}{ Graduation, output } & $\%$ of fulfillment of state order & 2 \\
\hline & & Number of bachelor graduates** & 4 \\
\hline & & Number of master graduates** & 5 \\
\hline & & Defended PhD thesis* & 5 \\
\hline & & Number of graduates/other student groups & 2 \\
\hline & & Employment rate of the graduates & 2 \\
\hline \multirow{10}{*}{$\begin{array}{l}\text { Development of } \\
\text { study programs }\end{array}$} & \multirow[t]{2}{*}{ Satisfaction } & Satisfaction of the graduates* & 3 \\
\hline & & Satisfaction of the students $*$ & 3 \\
\hline & \multirow[t]{4}{*}{ Study programs } & Share of joint study programs & 1 \\
\hline & & Number of study programs $* *$ & 4 \\
\hline & & Internal cooperation & 1 \\
\hline & & Number of international study programs* & 2 \\
\hline & E-study & Volume of E-study & 2 \\
\hline & \multirow[t]{3}{*}{ Quality assessment } & Accreditation* & 1 \\
\hline & & Benchmarking & 2 \\
\hline & & Doctoral schools & 2 \\
\hline \multirow{8}{*}{$\begin{array}{l}\text { Study } \\
\text { supporting } \\
\text { processes }\end{array}$} & \multirow[t]{4}{*}{ Internationalization } & Number/share of foreign students* & 5 \\
\hline & & Number/share of students studying abroad* & 4 \\
\hline & & Number/share of foreign teaching staff* & 4 \\
\hline & & Foreign offices & 1 \\
\hline & Retraining & $\begin{array}{l}\text { Amount of retraining courses/number of } \\
\text { participants* }\end{array}$ & 4 \\
\hline & \multirow[t]{3}{*}{ Personnel } & Number/share of academic staff* & 5 \\
\hline & & Qualification of academic staff* & 1 \\
\hline & & $\begin{array}{l}\text { Number of students per academic staff } \\
\text { member }\end{array}$ & 1 \\
\hline
\end{tabular}

*- indicators, presented in strategic documents as well as in management reports.

**- indicators, presented in management reports and partly also in strategic documents.

Source: the authors' analysis.

At the same time our analysis revealed that non-financial teaching performance indicators have been significantly presented also in development plans. Therefore, we can conclude that the strategic planning is in certain manner linked to other stages of the Deming's cycle in the area of teaching activities.

\subsection{Research activity performance measurement}

Performance indicators of research activities are distinguished into three groups: 1) doctoral studies; 2) R \& D resources, and 3) R \& D performance-related indicators. Our analysis revealed that the Estonian universities used 20 different indicators of research activities. Still, 
the use of indicators is very different among universities. All universities have presented in management reports only one indicator in dynamics, namely the dynamics of the number of defenses of $\mathrm{PhD}$ thesis in recent years. Four universities have presented the statistics of academic staff. Among R\&D resource-related indicators, the number of institutional research grants and other research grants are mostly presented and among $\mathrm{R} \& \mathrm{D}$ performance indicators the universities have focused on the number of publications. Rest of indicators are used only by one or two universities.

Cost calculations of research projects are generally based on the direct costing methods and the cost of a research projects is not reflecting the indirect costs associated with the corresponding activities. The problem of allocation of indirect costs often stems from the fact, that indirect costs of research activities are not eligible for research projects financed by EU structural funds, for example, to cover operating and maintenance costs of an equipment used. It revealed by the interviews that acquired research equipment can be duplicated by another university project, but at the same time are under-utilized.

Our analysis revealed that non-financial research performance indicators are in majority presented in development plans. Therefore, we can conclude that the strategic planning is in certain manner linked to other stages of the Deming's cycle in the area of research activity.

\subsection{Performance measurement of service to the society}

Service to society area is mostly unevenly reflected in the management reports of the universities. Partly is the service to society area a little uncertain due to the different areas of responsibility of the universities. Two of the six universities are not distinguished service to society as their main activity area within the management reports as it is recognized among teaching activity area. Hence there is a need for more substantial definition of the area and for design of corresponding performance indicators.

Basing on the conducted analysis we argue that performance indicators of service to the society activities can be distinguished into three groups: 1) public service development; 2) popularization of the areas of main activities, and 3) retraining and other public oriented training. Our analysis revealed that the Estonian universities used altogether 11 different indicators of service to society. All universities specify retraining as an area of service to the society and therefore five universities present the number of participants attended retraining courses, and number or volume (hours) of retraining courses in the management reports.

\section{Concluding remarks}

The present study investigated, using the PDCA (Plan, Do, Check and Act) cycle model, how Estonian universities present the performance indicators in their management reports to disclosure provision of public services. The use of performance measurement is assessed through disclosed performance information. Acknowledging the different contingencies influencing this cycle this paper explored which different performance indicators are presented to disclosure performance of three main areas of university operations - teaching, research and service to the society activities. For the purpose of this research we reviewed the planning and reporting documents of six Estonian public universities. The findings using this approach lead us to a number of observations.

Firstly, performance information on all three main areas of university operations - teaching, research and service to the society activities - have been disclosed in management reports of the universities, but service to the society indicators have been disclosed in less extent than other areas. 
Secondly, the universities use more financial performance indicators of absolute value, less are used ratio variables.

Thirdly, the financial and non-financial performance indicators are weakly linked within the performance measurement of the main areas of university operations.

Fourthly, considering the influential factors affecting the improvements of performance measurement, legal regulatory requirements continue to have a substantial impact in Estonian universities. Our analysis showed that there are several legal acts regulating different stages of PDCA-cycle model, but the requirements are first phrased in a very general manner and second the requirements for different stages of performance management have been incorporated stepwise to these regulations, resulting in an uneven and inharmonious development of performance measurement systems.

\section{Literature}

Bovens, M. (2005). The concepts of public accountability. In: The Oxford Handbook of Public Management, ed. by E. Ferlie, L. E. Lynne and C. Pollitt. New York: Oxford University Press, pp. 182-208.

Brandsma, G. J., Schillemans, T. (2013). The Accountability Cube: Measuring Accountability. Journal of Public Administration Research and Theory, vol. 23, pp. 953-975.

Chen, S., Yang, C., Shiau, J. (2006). The application of balanced scorecard in the performance evaluation of higher education. The TQM Magazine, vol. 8, no. 2, pp. 190-205.

Coy, D., Fischer, M., Gordon, T. (2001). Public accountability: a new paradigm for college and university annual reports. Critical Perspectives of Accounting, vol. 12, no. 1, pp. 1-31

Coy, D., Dixon, K. (2004). The public accountability index: crafting a parametric disclosure index for annual reports. British Accounting Review, vol. 36, issue 1, pp. 79-106.

Deming, W. E. (2000). The New Economics for Industry, Government, Education. 2nd ed. Cambridge: The MIT Press.

Epstein, P. D., Campbell, W. (2002). Use and the Effects of Using Performance Measures for Budgeting. Research report. Management and Reporting.

Greiling, D. (2010). Balanced scorecard implementation in German non-profit organizations. International Journal of Productivity and Performance Management, vol. 59, no. 6, pp. 543554.

Greiling, D., Spraul, K. (2010). Accountability and the Challenges of Information Disclosure. Public Administration Quarterly, vol. 34, no. 3, pp. 338-377.

Grossi, G., Reichard, C., Ruggiero, P. (2016). Appropriateness and Use of Performance Information in the Budgeting Process: Some Experiences from German and Italian Municipalities. Public Performance and Management Review, vol. 39, pp. 581-606.

Guthrie, J., Neumann, R. (2007). Economic and non-financial performance indicators in universities. Public Management Review, vol. 9, no. 2, pp. 231-252.

Hood, C. (1995). Contemporary public management: a global paradigm? Public Policy and Administration, vol. 10, no. 2, pp. 21-30.

Horváth, P., Moeller, K., Schwab, C. (2006). Value-added services in German industrial companies - a study of the implications for Management Accounting, Paper presented at the 29. Annual Congress of European Accounting Association, March, Dublin, Ireland. 
Kallio, K-M., Kallio, T. J. (2014). Management-by-results and performance measurement in universities - implications for work motivation. Studies in Higher Education, vol. 39, no. 4, pp. 574-589.

Kaplan, R., Norton, D. (1992). The balanced scorecard: the measures that drive performance. Harward Business Review, January-February, pp. 75-85.

Kuah, C. T., Wong, K. Y. (2011). Efficiency assessment of universities through data envelopment analysis. Procedia Computer Science, vol. 3, pp. 499-506.

Lapsley, I. (2008). The NPM Agenda: Back to the Future. Financial Accountability and Management, vol. 24, no. 1, pp. 60-77.

Lawrence, S., Sharma, U. (2002). Commodification of education and academic Labour Using the Balanced Scorecard in a University Setting. Critical Perspectives of Accounting, vol. 13 , no. 5, 661-677.

Melkers, J., Willoughby, K. (2005). Models of Performance-Measurement Use in Local Governments: Understanding Budgeting, Communication, and Lasting Effects. Public Administration Review, vol. 66, no. 2, pp. 180-190.

Messner, M. (2009). The limits of accountability. Accounting, Organizations and Society, vol. 34, pp. 918-938.

Modell, S. (2003). Goals versus institutions: the development of performance measurement in Swedish university sector. Management Accounting Research, vol. 14, pp. 333-359.

Pallot, J. (2001). Transparency in local government: antipodean initiatives. The European Accounting Review, vol. 10, no. 3, pp. 645-660.

Schedler, K., Siegel, J. P. (2005). Strategisches Management in Kommunen. Düsseldorf: Hans-Böckler-Stiftung.

ter Bogt, H. J. Scapens, R. W. (2012). Performance Management in Universities: Effects of the Transition to More Quantitative Measurement Systems. European Accounting Review, vol. 21, no. 3, pp. 451-497.

Van der Stede, W. (2011). Management Accounting Research in the Wake of the Crises: Some Reflection. European Accounting Review, vol. 20, no. 4, pp. 605-623.

Warning, S. (2004). Performance Differences in German Higher Education: Empirical Analysis of Strategic Groups. Review of Industrial Organization, vol. 24, pp. 393-408.

Vernau, K. (2014). Herausforderungen des strategischen Controllings an Hochschulen", Controlling, vol. 25, no. 10, pp. 556-564.

Worthington, A. C., Lee, B. L. (2008). Efficiency, technology and productivity change in Australian universities, 1998-2003. Economics of Education Review, vol. 27, pp. 285-298. 